\title{
Low Contribution Of Fishermen's Wives To Family Income On Seafishing Industrial Sector In Indonesia (A Case Study In Rembang, Central Java, Indonesia)
}

\author{
Rispantyo $^{1}$, Setyasih Harini' ${ }^{2}$, Fadjar Harimurti ${ }^{1}$, Riska Fii Ahsani ${ }^{3}$, Nolaila Binti Abdulah Chik ${ }^{4}$, Pn. \\ Sharifah Sofia Atiqah Syed Ibrahim ${ }^{5}$, Pn. Rosfaraliza Azura Ramli ${ }^{6}$ \\ ${ }^{1}$ Accounting Study Program, Universitas Slamet Riyadi, Central Java, Indonesia \\ ${ }^{2}$ International Relations Science Study Program, Universitas Slamet Riyadi, Central Java, Indonesia \\ ${ }^{3}$ Management Study Program, Universitas Slamet Riyadi, Central Java, Indonesia \\ 4,5,6 Universiti Utara Malaysia, Malaysia
}

\begin{abstract}
Majority of the coastal community members in Indonesia still rely their life on fishing. Most of fishermen in the community are small-scale fishers, fishing workers, small-scale fish processors, and small traders. Efforts to obtain a larger income need support from family members. The role of husbands as the heads of family, responsible in earning a living, needs to be supported by their wives. The role of wives is as their husbands' helpers in acquiring a livelihood as to raise their family income. The objective of this research is to analyze factors influencing women to enter workforce and their contribution to raising their family income. To analyze the case, theories of gender and development, women empowerment, and family economy are needed. This research used quantitative methodology. Its samples consisted of 85 fishermen's wives from several villages that have active fish processing home industry in Rembang, Central Java. The results of research show that the income contribution of fishermen's wives to the family income was still low, amounting to $33.13 \%$. Factors influencing the wives to take up work were their education level and their motivation to work, while factors influencing their income were time allotted to work and types of work.
\end{abstract}

Keywords:

Contribution, wife, fisherman, income, family

Article Received: 18 October 2020, Revised: 3 November 2020, Accepted: 24 December 2020

\section{INTRODUCTION}

\section{Background}

The main source of income of communities living in the coastal area is fishing, conducted by fishermen. They depend their living on the use of marine and coastal resources. Using marine resources to generate large profits needs the same large number of investments. Most of the fishermen in this area operate on a small scale, or work as fishing workers, small-scale fish processors, and small traders. It is because of their limited investment ability. Endeavors in acquiring larger income need support from family members. Each of them should be able to perform their duties. A husband as the head of the family is responsible for earning family living. The wife should be able to manage family economy well.
Coastal communities are vulnerable to various problems potentially causing poverty. One of the problems that they encounter is what effort they have to do to raise family income. They always strive to find a way in order for poverty not to happen. One of those ways is the empowerment of family members as part of the workforce, such as wives. Wives are involved in the effort to find additional income for their families. The role of wives becomes important since they are not only acting as housewives but also working to help their husbands to raise their families' income. To date, however, the roles have not received much attention. Thus, a study on the contribution of women to family income is needed.

There have been several researches regarding women's contribution to family income. 
Female workforce has been found in various sectors. For example, there have been researches on the role of female workforce in the dairy industry (Suherman, Amalia, and Gunawan, 2018), in fruit selling (Astuti, Fachruddin, and Sutarto, 2012), in fisheries (Widodo, 2012), in rubber plantation (Fitriyana, 2018), in farming (Sawangponto, Miniaga, and Kumaat, 2019), in tea plantation (Sumantri and Ansori, 2004), in batik industry (Indranjoto and Wulandari, 2018), and in salted fish trade (Aulia, Usman, and Susanti, 2018). These sectors are diverse. This research analyzes women's contribution to family income raise in the marine fisheries sector.

Based on the former researches, it can be illustrated that the effort to prosper the family does not solely rest on the shoulders of the husband, but also the wife/housewife, which plays a helping role. This research analyzes women in their effort to raise their families' income. The research was conducted in Rembang Regency, Central Java. The sub-district of Rembang has thirteen village administrations (desa/kelurahan) whose people work as fishermen. The thirteen village administrations are Tritunggal with 334 resident fishermen, Pasar Banggi with 544 resident fishermen, Kebongan Lor with 194 resident fishermen, Sukoharjo with 201 resident fishermen, Pandean with 77 resident fishermen, Tasikagung with 526 resident fishermen, Tanjungsari with 504 resident fishermen, Pacar with 337 resident fishermen, Gegunung Wetan with 337 resident fishermen, Gegunung Kulon with 206 resident fishermen, Banyudono/Pantiharjo with 130 resident fishermen, Tanggulsari with 269 resident fishermen, and Magersari with 269 resident fishermen (Ekadianti, 2014). The data show that Tasikagung village administration is the region with most resident fishermen. The fishermen's wives also support their husbands' activities by making fisheries their main livelihood.

\section{Problem statement}

Rembang is one of the coastal regions in
Java whose most of the people work as fishermen and catch processors. The work of fishers in Rembang is generally taken by men. The women (fishermen's wives), aside of their main role as housewives, are also involved in the marine produce cultivation activities. Based on the descriptions above, the problem statements are formulated as follows:

1. What are the factors influencing women/housewives to take on work?

2. How is their contribution to raising family income?

The objective of this research is to:

1. Analyze factors influencing women's decision to work.

2. Analyzing amount of women's contribution to raising family income.

\section{LITERATURE REVIEW}

A nuclear family consists of a father, a mother, and their children. A family is the smallest unit of a society. Family members are the most important part of a household. A family can be considered as prosperous one if their welfare is guaranteed and their condition is healthy and peaceful. A healthy and welfare-guaranteed family is the initial step of the making of a prosperous family. Hassan et al. (2012) explained that a healthy and prosperous family is reflected on their ability to avoid divorce and social diseases. This kind of family can also be identified by the freedom of their women to earn their livelihood respectably. Oftentimes, women get a connotation as God's creature destined to be domestic workers (homemakers), and therefore they do not contribute to family income.

Javanese society especially still views women as not worthy to take a leading role in a profession. This cannot be separated from the view that women mostly hold on to their emotion which makes them difficult to make a decision wisely (Tuwu, 2018). These societal views and stigmas are then legitimized in the gender-based division of line of work hold true until now. This condition makes women a group of society prone 
to poverty. As explained by Harini (2019), gender inequality in economy makes women increasingly deceived and deluded as captive of patriarchal culture which makes them easy to fall into poverty and therefore a socio-economic empowerment is needed.

Women empowerment cannot be separated from the efforts to explore the abilities and potentials they possess (Rowland 1997, Rahman Aminur 2013). There are four things that should exist here: (1) power (courage) to control their possessed power, that they must dare to resist if needed to respond back compliance forced on them; (2) power to create something new without domination and pressure from others; (3) power to become an independent individual able to solve problems; (4) spiritual power to grow to be a real human able to respect and accept others.

In relation to women empowerment effort, there are three approaches attached to it: (1) Women in Development (WID): This concept is a strategy based on liberal feminist theory. The theory integrates women role into development process. The development in process cannot go smoothly without women participation; (2) Women and Development (WAD): This concept is an implementation of Neo-Marxist approach based on theory of global interdependence. In WAD context, women should be given the same opportunities and roles with men in terms of work according to their ability; and (3) Gender and Development (GAD) that attempts to analyze women role based on socialist feminist theory: GAD strategy instead gives pressure to government role in supporting and protecting women's emancipation. The state is tasked in supporting social services provided for women through education and training to improve independence (Rahutami, 2017). The three approaches can help with the effort to combat poverty experienced by women.

\section{RESEARCH METHODS}

This research used mixed method, a combination of quantitative and qualitative method. The research was conducted in Rembang. The population for this research was 20 fishermen's wives. Total sampling was used to determine its samples, in which all members of the population were used as research respondents. The data consisted of primary and secondary ones. The former were obtained from the research field through in-depth interviewing to the respondents by using instrument of questionnaire. The latter were obtained from related government agencies (stakeholders in marine production in Kabupaten Rembang). The secondary data were also equipped with studies of literatures, journals, and articles related to research topic. In this research, the researchers needed informants to help collect the information used to analyze wives' contribution in raising hou sehold income.

Contribution of wives in the effort of raising family income was calculated by using the following formula, adapted from Sawangponto, et al. (2019)

\section{Housewives'}

income

Contribution of housewives $=$

$--\mathrm{X} 100 \%$

income

Total family

in which total family income is equal to husband income + wife income.

Pieces of information needed in measuring variables in this research are:

1. Respondents' characteristics:
a. Name
b. Age (in years)
c. Number of family dependents (people)
d. Formal and non-formal education

2. Husband's line of work

3. Children's line of work

4. Income from types of marine produce cultivation

5. Sum of turnover (Rps) per month

6. Income within family:

a. Husband's income (Rps/month) 
b. Wife's income (Rps/month)

c. Income from children already working (Rps/month)

In order to determine level of housewives' contribution to family income, the researchers employed a formula claimed by Widodo (2001) who categorizes them into four categories:

1. Very low $:<25 \%$

2. Low : $25 \%-49 \%$

3. High : $: 50 \%-75 \%$

4. Very high $:>75 \%$

Pieces of information needed in measuring variables in this research are:

1. Respondents' characteristics
a. Name
b. Age (in years)
c. Number of family dependents (people)
d. Formal and non-formal education

2. Types of fishermen's wives' occupation

3. Time allotted by fishermen's wives to their occupation

4. Fishermen's wives' motivation to work

5. Income within family:
a. Family income (Rps/month)
b. Wife income (Rps/month)

\section{RESULTS}

\section{General condition of fishermen's wives}

Community empowerment is strongly important to coastal communities depending their livelihood on marine produce. Empowerment as a process of development becomes an initiation for community activities to improve situations and conditions that they encounter. Empowerment referred to in this study is interpreted as a process of liberation of individual and society to improve their ability, capacity, freedom, and creativity (Kadir, Munir, and Wahda, 2017). So far, the construct developed by coastal communities still shows existence of gender-based division of line of work, in which women are considered not worthy fishing at sea (Carrie L. Yodanis, 2000), and that the challenges of working at sea are considered too heavy for women in fishing communities (Chandra, G. and A P. Sharma. 2014)

These ideas illustrate the role of women, in which they are not considered as main breadwinners but as helpers in improving family income. Ever-pressing economic demands encountered by fisher families in Rembang, Central Java, especially in relation to the uncertainties of husband's income become the reason for fishermen's wives to have activities other than domestic (daily housewife activities in general) and other social activities. Coastal women cannot refuse themselves from dealing with the seas and its wealth (Sruthi, Jalayal, \& Gopal, 2016). Coastal women need empowerment so that they can become independent. Women empowerment cannot be separated from the efforts to explore the abilities and potentials they possess (Rowland 1997, Aminur 2013). There are four things that should exist here: (1) power (courage) to control their possessed power, that they must dare to resist if needed to respond back compliance forced on them; (2) power to create something new without domination and pressure from others; (3) power to become an independent individual able to solve problems; and (4) spiritual power to grow to be a real human able to respect and accept others.

Firstly, Rembang fishermen's wives explore their abilities so that they can respond back to the realities and difficulties of life that they encounter; secondly, they attempt to create and conduct innovation so that they are no longer under domination and pressure of their husband as the main breadwinners; thirdly, the power of fishermen's wives as individuals are harnessed with the help and touch from others, in form of invitation to become more independent and able to solve problems on their own; fourthly, with the power and abilities they possess, fishermen's wives grow spiritually and physically to be able to respect and accept others. These are proven by Rembang fishermen's wives, the object of this research, in which they not only play a role in 
nurturing children, housekeeping, etc. but also are actually involved in economic activities, directly contributing to improving family income.

\section{Fishermen's wives' income level}

In general, the line of occupation conducted by respondents in location of research is occupation that instantly makes money, such as those involving direct waging work system and those of buying and selling. Thus, the fishermen's wives can immediately get paid after work. As explained by a fisherman's wife from Gegunung Kulon village, her daily activities beside housekeeping include making fish crackers (kerupuk ikan) sold to the subdistrict market, while other fisherman's wife from Pangkalan Sluke said that she has to sell processed products of catches by peddling it around the villages. Even so, the sales results are not maximum enough, but the additional income obtained can help raise family income, in which it does not only depend on her husband (field note, July $8^{\text {th }}, 2020$ ). Average income of fishermen's wives is relatively lower than their husbands' income (Table 1). Even so, additional income generated by fishermen's wives is very helpful in making ends meet for fisher households.

Table 1. Average income per month

\begin{tabular}{lc}
\hline Description & Amount (Rps/month) \\
\hline Average income of fishermen's wives & 982,353 \\
Average income of husband & $1,982,353$ \\
\hline Average total family income & $\mathbf{2 , 9 6 4 , 7 0 6}$ \\
\hline
\end{tabular}

Source: Processed Primary Data, 2020

Income contribution of fishermen's wives

The average contribution of income from fishermen's wives amounted to $33.13 \%$, meaning that they contribute about $33.13 \%$ of total family income. Development and empowerment of communities around the coast are done by strengthening women capacity in contributing to development. Therefore, genderbased strengthening of capacity is needed. (Bennett, 2005). Fishermen's wives working in fisheries sector is the most mainstream line of work with $82.4 \%$ percentage, by helping processing catches from the fishers. Catch processing is until now still viable as a dominant addition to the family income since "working in other sectors cannot necessarily be done by fishermen's wives. Therefore, their involvement in processing catches is essential," one of fishermen's wives from Tunggul Sari village stated (field note, July $\left.9^{\text {th }}, 2020\right)$. The rest of them $(17.6 \%)$ work as teachers, grocery traders, tailor, and others. Contributions from fishermen's wives will be much higher if they contribute higher income to the family income.

Table 2. Income contribution

\begin{tabular}{lll}
\hline Description & $\begin{array}{l}\text { Amount } \\
\text { (Rps/Month) }\end{array}$ & $\begin{array}{l}\text { Contribution } \\
(\boldsymbol{\%})\end{array}$ \\
\hline Average income of fishermen's wives & 982,353 & 33.13 \\
Average income of husbands & $1,982,353$ & 66.87 \\
\hline Average total family income & $2,964,706$ & $\mathbf{1 0 0 . 0 0}$ \\
\hline
\end{tabular}

Source: Processed Primary Data, 2020 
than expenditures for non-food consumption. Average total of family consumption expenditure per month is Rp4,223,528.00. From the total family consumption expenditure, average expenditure for food consumption amounted to Rp2,247,058.00 or $53.20 \%$ of total expenditure, while average expenditure for nonfood consumption amounted to Rp1,976,528.00 or $46.80 \%$ of total expenditure.

The average total of the respondents' family consumption expenditure, amounting to
Rp4,223,528.00 that is significantly smaller than the average total of the respondents' family income, amounting to Rp2,964,706.00 can be interpreted as an imbalance, in which expenditures exceeds income. It is because the respondents enter banking credit payments as a form of expenditure. However, if data from individual households were to be examined, there were several households that have lower expenditures than their income.

Table 3. Average consumption expenditure of respondents' family

\begin{tabular}{lll}
\hline \multicolumn{1}{c}{ Type of income } & $\begin{array}{l}\text { Amount } \\
(\mathbf{R p})\end{array}$ & Percentage (\%) \\
& $2,247,058$ & 53.20 \\
Food & $1,976,528$ & 46.80 \\
Non-Food & $\mathbf{4 , 2 2 3 , 5 2 8}$ & $\mathbf{1 0 0 . 0 0}$ \\
\hline Total &
\end{tabular}

Source: Processed Primary Data, 2020

Factors influencing wives to work based on age

Table 4 shows that all respondents are on the productive, working age, falling on the range of 15-64 years old. From the research results, it is understood that youngest respondent was 21 years old, while the oldest was 58 years old, with the average age of the respondents was 30-50 years old. Based on the interviews conducted, respondents stated that age is not a hindrance for them in doing their job. As long as they are healthy and strong, they will always try to work as best as they can. As said by fishermen's wives of Tunggul Sari village that their involvement in helping their husband earn their living is genuinely needed. The statement is strengthened by the Head of Tunggul Sari village administration, stating that nearly all women from the village is taking up work in order to raise family income (field note, July $9^{\text {th }}, 2020$ ). It is done since majority of the respondents opined that earnings from one person/their husband are still lacking to make ends meet.

Table 4. Respondents' age group

\begin{tabular}{lcll}
\hline No & Age group & $\begin{array}{l}\text { Number } \\
\text { (People) }\end{array}$ & Percentage (\%) \\
\hline 1 & $<15$ years old & - & - \\
2 & $15-64$ years old & 85 & 100 \\
3 & $>64$ years old & - & - \\
\hline & Total & $\mathbf{8 5}$ & $\mathbf{1 0 0}$ \\
\hline
\end{tabular}

Source: Processed Primary Data, 2020

\section{Education level}

Research results show that a majority of fishermen's wives, or $40 \%$ of the respondents only passed Elementary School (Sekolah Dasar 
- SD). $32.9 \%$ of the respondents passed Junior High School (Sekolah Menengah Pertama SMP), 20\% passed Senior High School (Sekolah Menengah Atas - SMA), while only 5.9\% graduated with Bachelor's Degree (Strata 1 S1). The results are shown in the following Figure 1.

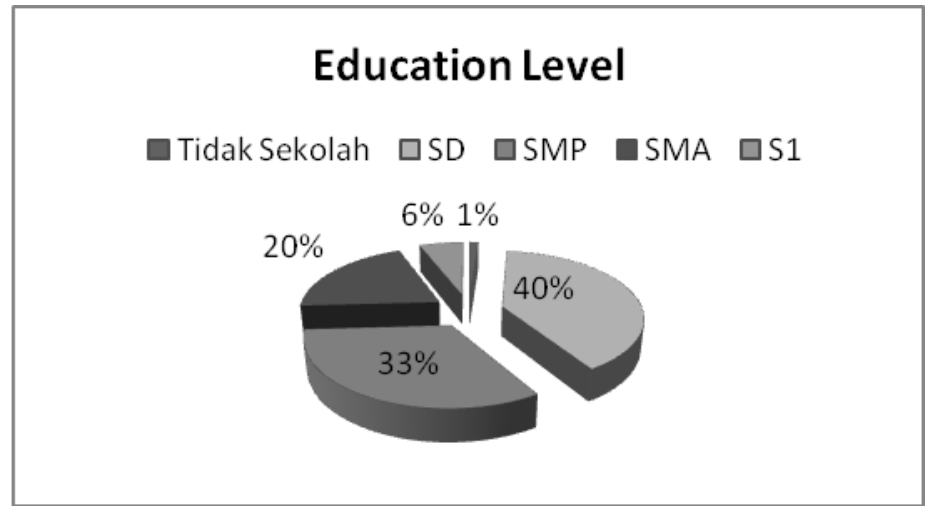

Figure 1. Respondents' education level (Source: Processed Primary Data, 2020)

\section{Motivation to work}

There are a number of things motivating fishermen's wives to work, including the wish to raise family income, the desire to be more independent, or the encouragement from their husbands. The result of the survey shows that $80 \%$ of the fishermen's wives sampled work because they want to raise their family income. It correlates with the amount of family expenditure that turns out to be larger than their income. Indirectly, the number of family dependents also gives individual motivation for fishermen's wives to work. The result is strengthened by the opinion from fishermen's wives, obtained through Head of Subsection of Maritime and Fisheries Agency of Rembang Regency that women nowadays have motivation to work to help their husbands in accordance with their ability. Wives of Rembang fishermen received training, guidance, and accompaniment in sea catch processing in order to be able to help their husbands earn their livelihood (field note, July $8^{\text {th }}, 2020$ ).

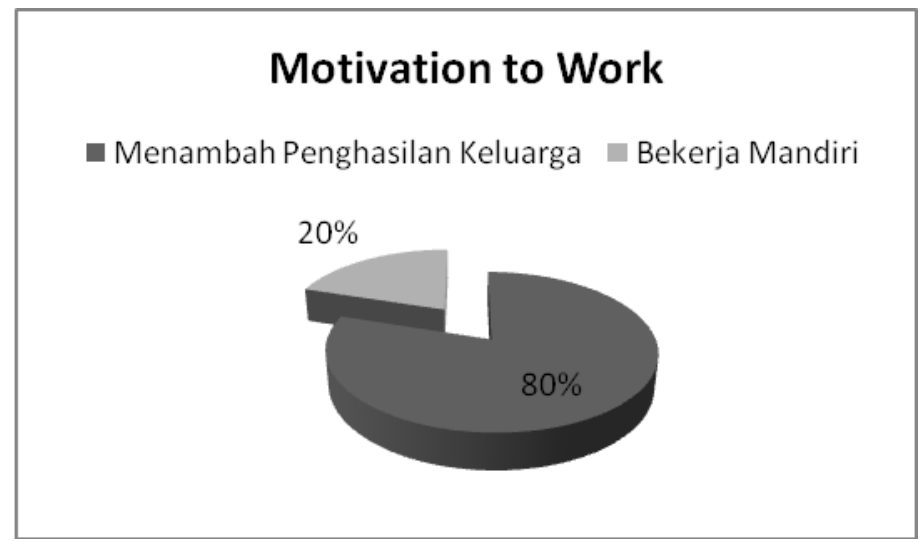

Figure 2. Respondents' motivation to work (Source: Processed Primary Data, 2020)

The interview results show that the motivation of fishermen's wives in working is to raise family income by processing their husbands' catches other than fish, like crabs. Generally, transaction of crabs is conducted between fishermen's wives and suppliers coming each week. The price put on by suppliers for raw crabs is 33.000 rupiahs, while those ready to eat can reach 140.000 rupiahs. These other-than-fish processed products have also been marketed 
overseas, including Singapore, Taiwan, and the United States. Sale of processed catches other than fish indeed helps to raise family income, since thus far, many of fishermen's wives only depend on their husbands' income, obtained from sale of raw catches, while they only keep themselves busy in the domestic, home affairs, causing the lack of personal income. This effort by fishermen's wives can reduce their poverty level (field note, July $8^{\text {th }}, 2020$ ).

There are three important levels to improve social capital in order to reduce poverty: trust, social norms, and social networks (Putnam, 1995; Fukuyama, 2001). Within Rembang fishing communities there exist a strong bond of trust, bearing in mind their background of living that depends on sea produces. The trust is then fostered and grown by the fishermen's wives, so that a strong social network is formed. This trust becomes a shared social capital in economic activities, which is a shared motivation between the fishermen's wives to form social networks in the effort to raise family income. The social networks are formed to the level of social norms as a shared value of helping each other in order to reduce poverty. The study conducted by Noegroho and Ardiani (2017) shows that in order to ease process of sustained development, a synergy between community members is necessary. The synergy is then supported with social communication and relations referring to shared goal, such as reducing poverty.

\section{Number of family dependents}

Number of family dependents, consciously or not, can be one of the motivations for fisher families to work. A large number of family dependents usually motivates workers, having a role as the backbone of the family, either the husbands or the wives, to work harder to meet their family's needs.

Table 5. Number of dependents in respondents' families

\begin{tabular}{llll}
\hline No & Number of family dependents & $\begin{array}{l}\text { Number } \\
\text { respondents }\end{array}$ & ofPercentage (\%) \\
\hline $1-2$ & 41 & 48.20 \\
$3-4$ & 35 & 41.20 \\
& $5-6$ & 9 & 10.60 \\
\hline Total & $\mathbf{8 5}$ & $\mathbf{1 0 0}$ \\
\hline
\end{tabular}

Source: Processed Primary Data, 2020

\section{Factors influencing income of fishermen's wives}

Work time allotment

Average time allotted by fishermen's wives to work is approximately 5-6 hours per day (Figure 3). Based on the survey on fishermen's wives in Rembang, it is understood that only $1.7 \%$ of them who work for 1-2 hours a day. The majority of fishermen's wives work for 3-4 hours a day to sort out catches and to clean them before they sell them to market, with $40 \%$ percentage. $27.1 \%$ of respondents work for 5-6 hours a day, followed by $14.1 \%$ of respondents working for 7 8 hours, and at last, $11.8 \%$ respondents work for more than 8 hours a day. The respondents working for more than 8 hours a day work at manual fish processing industries, such as fish smoking, which consumes a lot of time. 


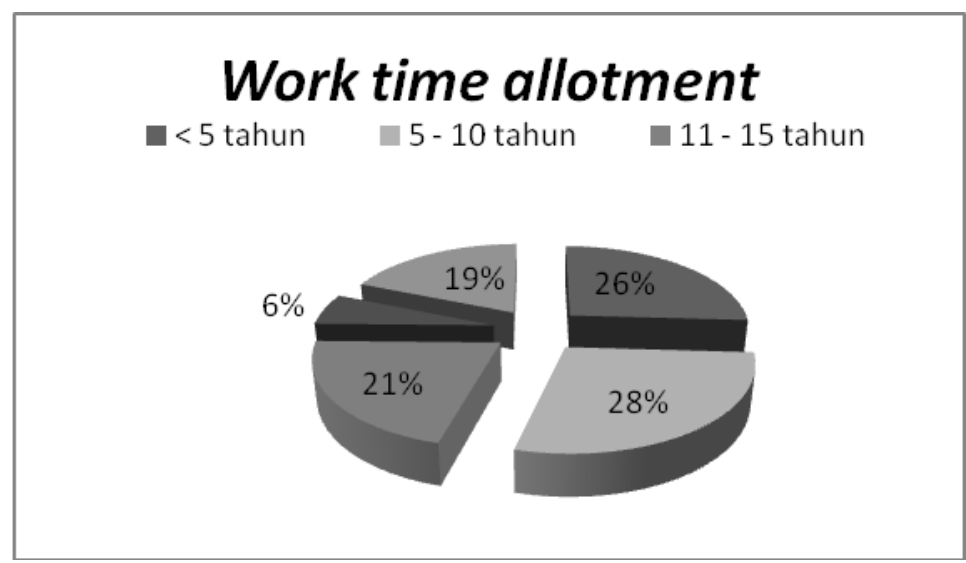

Figure 3. Work time allotment

Table 6. Number of respondents based on work experience

\begin{tabular}{clll}
\hline No & $\begin{array}{l}\text { Work experience } \\
\text { (in years) }\end{array}$ & $\begin{array}{l}\text { Number } \\
\text { (people) }\end{array}$ & $\begin{array}{l}\text { Percentage } \\
(\%)\end{array}$ \\
\hline$<5$ & 22 & 25.9 \\
$5-10$ & 24 & 28.2 \\
$11-15$ & 18 & 21.2 \\
$15-20$ & 5 & 5.9 \\
$>20$ & 16 & 18.8 \\
\hline Total & $\mathbf{8 5}$ & $\mathbf{1 0 0}$ \\
\hline
\end{tabular}

Source: Processed Primary Data, 2020

Average respondents have 5-10 years of work experience, amounting to $28.2 \%$, while the least percentage of period of work experience, amounting to $5.9 \%$ is at $16-20$ years. The interesting phenomenon from the survey of work experiences is that the fishermen's wives become workers after they become one, while $18.8 \%$ of respondents have worked for over 20 years, starting from their time as daughters of fishermen and continuing to present day as wives of fishermen.

\section{Role Division of Fisher Families}

Table 7. Role division in respondents' families

\begin{tabular}{llll}
\hline No & Activities & Husband & Wife \\
\hline 1 & Livelihood earning & $\checkmark$ & $\checkmark$ \\
2 & Child education & $\checkmark$ & $\checkmark$ \\
3 & Child nurturing & & $\checkmark$ \\
4 & House chores & & $\checkmark$ \\
5 & Financial & \\
& management & $\checkmark$ \\
6 & Food needs & & $\checkmark$ \\
7 & Clothing needs & & $\checkmark$ \\
8 & Housing needs & $\checkmark$ & $\checkmark$ \\
9 & Health issues & $\checkmark$ & \\
\hline
\end{tabular}

Source: Processed Primary Data, 2020 
Table 7 shows that wives play more role in the family than husbands, since husbands working as fishermen are not usually at home every day. Once they are at home, they spend their time to rest and recharge for next fishing activities. It can be admitted that wives almost play all roles in the respondents' families, including acquiring livelihood, educating and nurturing children, doing house chores, managing home finances, buying foods and clothing, and in health-related issues.

\section{CONCLUSION}

Based on the results of the research, conclusions are drawn as follows:

1. The line of work of fishermen's wives in Rembang, Central Java, Indonesia in contributing to family income includes salted fish processors, smoked fish processors, fish vendors, crab peeler, ranginang/peyek maker, phone carrier credit vendor, washing workers, grocery trader, and teacher.

2. Average contribution of fishermen's wives to fisher family income in Rembang, Central Java, Indonesia amounts to $33.13 \%$.

3. Factors influencing fishermen's wives to take up work include education level and motivation to work. Age has no influence in this since fishermen's wives expects to work in an indefinite time, notwithstanding their age.

4. Factors influencing fishermen's wives' income are time allotment and type of work. Experience has no influence because the period devoted by fishermen's wives to their line of work does not correlate positively with the amount of income.

\section{SUGGESTIONS}

This research found that fishermen's wives have their share of contribution to the fishing family economy in Rembang, Central Java, Indonesia. The contribution can, without doubt, be raised to another level so that economic problem encountered by the pre-prosperous fisher families can be dealt with, and their prosperity can be improved. The government is expected to deliver appropriate actions to wives of fishermen in order to strengthen their contributions by holding counselling sessions aimed at developing creative business, so that they not only become menial workforce but also have the opportunity to develop entrepreneurial business.

\section{REFERENCES}

[1] Astuti, Asri WW, Fachrudin, dan Joko Sutarto. 2012. Peran Ibu Rumah Tangga Dalam Meningkatkan Kesejahteraan Keluarga (Suatu Kajian Pemenuhan Kebutuhan Pendidikan Anak pada 5 Ibu Pedagang Jambu Biji di Desa Bejen Kabupaten Temanggung). Journal of NonEducation and Community Empowerment, $1(2)$.

[2] Aulia, Muhammad Rizki, Mustafa Usman dan Elly Susanti. 2018. Motif dan Kontribusi Pendapatan Perempuan Pedagang Ikan Asin Terhadap Peningkatan Ekonomi Rumah Tangga Nelayan. Jurnal Ilmiah Mahasiswa Pertanian Unsyiah, 3 (4) November.

[3] Bennett, 2005. Gender, Fisheries and Development, Marine Policy (451-459), doi:10.1016/j.marpol.2004.07.003.

[4] Chandra, G. and A P. Sharma. 2014. Gender role in inland fisheries of India: A cross country study. 5th Global Symposium on Gender in Fisheries and Aquaculture, organised by Asian Fisheries Society at ICARNBFGR, Lucknow, India.

[5] Ekadianti, Martia, 2014. Analisis Pendapatan Istri Nelayan Dalam Upaya Meningkatkan Pendapatan Keluarga di Desa Tasikagung, Kecamatan Rembang, Kabupaten Rembang, Fakultas Ekonomika dan Bisnis, Universitas Diponegoro.

[6] Fitriyana, Gusti. 2018. Kontribusi Perempuan Tani terhadap Pendapatan 
Usaha Tani Karet di Desa Sugiraya Kecamatan Babat Tomon Kabupaten Musi Banyuasin. Jurnal TriAgro, 3 (1) FebruariJuni.

[7] Fukuyama, Francis, 2001. Social Capital, Civil Society and Development, Third World Quartely, Vol. 22 No. 1, (7-20).

[8] Hanum, Septi Latifa. 2017. Peran Ibu Rumah Tangga Dalam Membangun Kesejahteraan Keluarga. Academica, 1 (2) Juli-Desember.

[9] Harini, Setyasih, 2019. Manfaat Penggunaan Pranata Mangsa Bagi Petani Desa Mojoreno Kabupaten Wonogiri, Jurnal Inada, 2(1), Kajian Perempuan Indonesia di Daerah Tertinggal, Terdepan dan Terluar (1-17).

[10] Hassan, Amran, dkk, 2012. Keluarga Sihat Melahirkan Komuniti Sejahtera: Satu Ulasan, GEOGRAFIA Online Malaysia Journal of Society and Space 8 issue 5 (51 - 63).

[11] Rahman, Aminur, 2013, Women's

Empowerment: Concept and Beyond,

Global Journal of Human Social Science

Sociology and Culture, Volume 13 Issue 6

Version 1.0, (8-13).

[12] Rahutami, Angelina Ika dan Shandy Matitaputty, 2017. "Gender Issues of Poverty Alleviation in Indonesia 1," South East Asia Journal Contemporary Business, Economics and Law, 3(2), 25-35.

[13] Rowlands, 1997. Questioning Empowerment, Working with Women in Honduras, UK and Ireland: Oxfam Print Unit.

[14] Kadir, Nuraini, Abdul Razak Munir, dan Wahda, 2017. Analysis of Coastal Women Empowerment Models in Takalar Regency, $2^{\text {nd }}$ International Conference on Accounting, Management and Economics, 219-229.

[15] Kurniawati, Eni, Fendria Sativa, dan Aulia Farida. 2018. Kontribusi Pendapatan Tenaga Kerja Perempuan Pencukil Kelapa
Dalam terhadap Pendapatan Rumah Tangga di Kecamatan Mendahara Kabupaten Tanjung Jabung Timur.

[16] Noegroho, N dan Y.M. Ardiani, 2017. Sustainability of Fisherman Village in Urban Area: Case Study Untia Fisherman Village, Makassar Indonesia, The International Conference on Eco Engineering Development, (7-18).

[17] Putnam, 1995. Bowling Alone: America's Declining Social Capital, Journal of Democracy, Vol.6(1), (65-78).

[18] Sawungponto, Astrodein, Vicky RBM, dan Ribka MK. 2019. Kontribusi Pendapatan Ibu Rumah Tangga terhadap Keluarga Petani di Desa Kie Ici Kecamatan Ibu Kabupaten Halmahera Barat. Agri-SosioEkonomi, 4 (2) MeiAgustus.

[19] Sianturi, Onixtin Octarina dan Wido Prananingtyas. 2018. Kajian Kontribusi UMKM Berbasis Rumah Eceng Gondok Melalui Penggunaan Internet terhadap Pendapatan Pelaku Usaha di Kawasan Rawapening. Jurnal Pembangunan Kota, $6(2)$

[20] Sosan, Isna. 2010. Peran Ganda Ibu Rumah Tangga Yang Bekerja Sebagai Tukang Amplas Kerajinan Ukir Kayu. Jurnal Komunitas, 2 (2).

[21] Sruthi, Liya Jalayal, \& Nikita Gopal, 2016. Gender Roles and Fisheries Along the Vembanad Estuarine System, the Journal of Asiaan Fisheries Society, 29S (193206).

[22] Suherman, Riski Amalia, dan Gugun Gunawan. 2018. Peran Tenaga Kerja Perempuan Pada Industri Menengah Cocola Internasional Bakery Kota Serang Provinsi Banten Terhadap Ekonomi Rumah Tangga. UNES Journal Social and Economics Research, 3 (2) Desember.

[23] Sumantri, Bambang dan Budi Ansori. 2004. Kontribusi Pendapatan Ibu Rumah 
Tangga terhadap Pendapatan Keluarga. AGRISEP, 2 (2) Maret.

[24] Thasya, Maya dan Said Muhammad. 2017. Pengaruh Pendidikan, Umur, dan Curahan Jam Kerja Ibu Rumah Tangga Terhadap Pendapatan Keluarga (Studi Kasus: Ibu Rumah Tangga Yang Bekerja di Industri Batu Bata di Desa Kajbu Kecamatan Baitussalam). Jurnal Ilmiah Manajemen, 2 (1) Februari.

[25] Telaumbanua, Marlina dan Mutiara Nugraheni. 2018. Peran Ibu Rumah Tangga dalam Meningkatkan Kesejahteraan Keluarga. Sosio Informa, 4 (2) Mei-Agustus.

[26] Tuwu, Darmin, 2018. Peran Pekerja Perempuan Dalam Memenuhi Ekonomi Keluarga: Dari Peran Domestik Menuju Sektor Publik, Al Izzah: Jurnal HasilHasil Penelitian-ISSN: 1978-9726 (p); 2541-0717 (e) Volume 13, Nomor 1 (6376).

[27] Widodo, Slamet. 2012. Peran Perempuan dalam Sistem Nafkah Rumah Tangga Nelayan. Proceeding Seminar Nasional, Juni.

[28] Widodo. 2001. Indikator Ekonomi. Penerbit Kanisius, Yogyakarta

[29] Yodanis, Carrie L, 2000. Constructing Gender and Occupational Segregation: Study of Women and Work in Fishing Communities, Qualitative Sociology, Springer Link, (267-290). 